\title{
HMGN4 wt Allele
}

National Cancer Institute

\section{Source}

National Cancer Institute. HMGN4 wt Allele. NCI Thesaurus. Code C52082.

Human HMGN4 wild-type allele is located in the vicinity of $6 \mathrm{p} 21.3$ and is approximately 9 $\mathrm{kb}$ in length. This allele, which encodes high mobility group nucleosome-binding domaincontaining protein 4 , is involved in the modulation of chromatin modifications. 